\title{
Comparative and Correlational Evaluation of the Phytochemical Constituents and Antioxidant Activity of Musa sinensis L. and Musa paradisiaca L. Fruit Compartments (Musaceae)
}

\author{
Barnabas Oluwatomide Oyeyinka (i) and Anthony Jide Afolayan \\ Medicinal Plants and Economic Development (MPED) Research Centre, Department of Botany, University of Fort Hare, \\ Alice 5700, South Africa \\ Correspondence should be addressed to Anthony Jide Afolayan; aafolayan@ufh.ac.za
}

Received 21 April 2020; Revised 23 June 2020; Accepted 17 July 2020; Published 6 August 2020

Academic Editor: Daiji Endoh

Copyright (c) 2020 Barnabas Oluwatomide Oyeyinka and Anthony Jide Afolayan. This is an open access article distributed under the Creative Commons Attribution License, which permits unrestricted use, distribution, and reproduction in any medium, provided the original work is properly cited.

\begin{abstract}
Secondary metabolites and their biological activity have pharmacological relevance in the prevention and therapeutic management of disease, including the facilitation of normal physiological processes through biochemical mechanisms. In this study, phytochemical constituents and antioxidant activity were evaluated quantitatively on the acetone, ethanol, and aqueous extracts of the flesh, and peel, as well as the boiled peel extract compartments of Musa sinensis L. and Musa paradisiaca L. fruits. Total phenol, proanthocyanidin, and flavonoid contents were estimated and measured spectrophotometrically. The free radical scavenging antioxidant capacity of the extracts was tested on DPPH (2,2-diphenyl-1picrylhydrazyl ethanol), ABTS (2,2'-azino-bis(3-ethylbenzothiazoline-6-sulphonic acid)), and FRAP (ferric reducing antioxidant power) assay models. Correlation between phytoconstituents and antioxidant activity was analysed using Pearson's coefficient. The results showed varying amounts of phytochemicals in the solvent extracts of the flesh and peel, including the boiled peel extract of $M$. sinensis and $M$. paradisiaca. All acetone extracts of $M$. sinensis flesh, $M$. paradisiaca flesh, and $M$. paradisiaca peel had the highest phytochemical contents, with the exception of the ethanol extract of $M$. sinensis peel which had the highest phenol content; just as on the overall scale, the peel compartments had generally higher phytochemical profiles than the soft flesh in both fruits. The boiled peel extracts of $M$. sinensis and M. paradisiaca had the highest ABTS $(0.03 \mathrm{mg} / \mathrm{mL})$ and DPPH $(0.03 \mathrm{mg} / \mathrm{mL})$ activity. Ferric reducing power (FRAP) was the highest in the ethanol extracts of $M$. sinensis flesh and peel, and $M$. paradisiaca flesh, while it was the highest in the acetone extract of $M$. paradisiaca at the peak concentration used $(0.1 \mathrm{mg} / \mathrm{mL})$. There was a significant negative correlation between the total phenol and flavonoid contents of $M$. sinensis flesh with its DPPH radical scavenging activity and proanthocyanidin content of $M$. paradisiaca flesh with its DPPH radical scavenging activity. The correlation outcomes indicate that none of the phytochemical constituents solely affected antioxidant activity; instead, a combination of the polyphenolic constituents contributed to antioxidant activity. This study shows the therapeutic potentials of the flesh and, importantly, the peel of $M$. sinensis and M. paradisiaca fruits on the basis of the polyphenolic constitution against free radicals and oxidative stress.
\end{abstract}

\section{Introduction}

The medicinal relevance of plants chiefly lies in their chemistry, and plant secondary metabolites, in particular, are the key natural products that essentially drive the pharmacological activities of plants. Their utility spans industrial production frontiers such as pharmaceuticals, nutraceuticals, and textiles. Medicinal plants are so regarded because they possess therapeutic properties and have active components useful for drug synthesis and relevant in phytomedicine. Alkaloids, quinones, coumarins, and flavonoid compounds have been implicated in pharmaceutical processes [1] and the prominence of herbal medicine in many underdeveloped and developing countries. Scientific 
articles report that plant extract used in phytomedicine has paved the way for improved therapeutic scientific insights towards the development of the empirical medicinal system [2]. Oxidative stress, which in principle alters the physiological dynamics and triggers equilibrium disruption, is linked to series of inflammatory diseases such as arthritis, gastric ulcers, vasculitis, and lupus erythematous, including protein and DNA damage. In this regard, antioxidants provide defence mechanism through the prevention of oxidative damage, which is a notorious tendency of free radicals [2]. These defence mechanisms are expressed through enzymatic and nonenzymatic processes, some of which include the peroxidase, polyphenol oxidase, and the glutathione in its reduced form [3]. Antioxidants are peculiar in action because they have the capacity for repair, suppression of free radical formation, and scavenging. In biological systems, antioxidants express their mechanism through chelation of metal ion, regulation of gene expression, and the coantioxidants. Fruits are sources of many nonenzyme antioxidants like vitamins, gallic acid, rutin, and quercetin $[4,5]$.

Phytochemical compounds are secondary metabolites naturally sourced from fruits, vegetables, and other plant products, amongst them are the phenolics, which are central to the signal and defence mechanism in plants. Polyphenols help in reducing the risk of neurodegenerative disease, leukaemia, vasorelaxation, and antiallergenic activity [6] as well as possessing the capacity to interact with antioxidant enzymes [7, 8] such as glutathione S-transferases and the NADPH: quinine oxidoreductase (NQO1) and preventing the initiation phase of carcinogenesis through the modulation of cytoprotective enzyme activation [9]. The significance of dietary phytochemicals has been put forward in terms of being responsible for distinct plant characters like aroma and colour pigmentation [10]. It has also been reported that several phytochemicals are integral in affecting cell proliferation and regulation of cell cycle [10]. They are active in a series of signalling pathways that are usually disrupted during tumour initiation and proliferation [11-13].

Banana and plantain, members of the Musaceae family (Musa spp.), are important food crops that supply energybased carbohydrates, including a wide spectrum of other nutritive components in human nutrition [14-16]. They are tropical herbaceous plants that grow up to heights reaching 9 metres, and are produced largely in the Asian, African, and South American regions; sweet fruits in the case of banana and for plantain are popularly cooked for food [17]. These plants have been implicated in agricultural and industrial uses, which make them valuable to the bioeconomy [18, 19]. Banana and plantain fruits possess very thick coverings known as the peels; however, they have low dietary incorporation status as they constitute waste because they are usually disposed during the consumption of the fruit pulp. It is with the foregoing that this study has been designed to evaluate polyphenolic constituents and biological activity of extracts across the compartments (flesh, peel, and boiled peel extract) of $M$. sinensis and $M$. paradisiaca fruits, with an aim to establish the phytomedicinal viability of the often neglected peel and boiled peel extract component. In so doing, this study seeks to project the peels of $M$. sinensis and $M$. paradisiaca as potential functional foods with medicinal, therapeutic, and nutritional value. With the foregoing, this study has been designed for the evaluation of the pharmacological potential in the extracts of $M$. sinensis and M. paradisiaca fruits, which will further validate the dietary medicinal value of the soft flesh and particularly the less utilised peels of the fruits.

\section{Materials and Methods}

2.1. Materials and Reagents. M. sinensis and M. paradisiaca fruits were obtained for this study from supermarkets in Alice and East London, located in the Amathole District Municipality, Eastern Cape Province, South Africa (latitude $32^{\circ} 43^{\prime} 28.66^{\prime \prime}$; longitude $26^{\circ} 34^{\prime} 5.88^{\prime \prime}$ ), and were authenticated by Professor C. N. Cupido, a taxonomist in the Botany Department, University of Fort Hare (UFH); afterwards, voucher specimens were deposited in the herbarium (UFH2019-11-001 and UFH-2019-12-002).

Analytical grade reagents were used for the phytochemical and antioxidant experimental assays, and they include the Folin-Ciocalteau's (FC) reagent, aluminium trichloride $\left(\mathrm{AlCl}_{3}\right)$, anhydrous sodium carbonate $\left(\mathrm{Na}_{2} \mathrm{CO}_{3}\right)$, sodium hydroxide $(\mathrm{NaOH})$, sodium nitrite $\left(\mathrm{NaNO}_{2}\right)$, sodium acetate, hydrochloric acid $(\mathrm{HCl}), 2,2-$ diphenyl 1-1-picrylhydrazyl (DPPH), 2,2'-azino-bis (3ethylbenzthiazoline-6-sulfonic acid) (ABTS), potassium persulfate $\left(\mathrm{K}_{2}, \mathrm{~S}_{2}, \mathrm{O}_{8}\right)$, ferric chloride $\left(\mathrm{FeCl}_{3}\right)$, vanillin, rutin, trichloroacetic acid (TCA), quercetin, catechin, gallic acid, and methanol.

Pulverization of soft flesh and peel samples was done with a food blender (HBF 500S series, Virginia, USA). The boiling of peel samples was done in a water bath (BUCHI B-480). Filtration of sample-solvent mixtures was done using a set-up of the Whatman filter paper, Buchner funnel, and vacuum pump. Aqueous extracts were chilled in a refrigerant chiller (PolyScience AD15R-40-A12E, USA). Freeze-drying of aqueous extracts was done with a freeze dryer (Ceramic Filter Core Drier CD 052), Oven-drying of soft flesh and peel samples was done in an oven (LABOTEC, Durban, South Africa). Homogenization of extracts was done on a shaker (Lasec Stuart Orbital Shaker SSL1); organic (acetone and ethanol) extracts were concentrated using a rotary evaporator (LABOROTA 4000 Heidolph). Absorbance spectra were measured with Hewlett Packard VR3000 PC spectrophotometer, $765 \mathrm{~nm}$.

2.2. Sample and Extract Preparation. The fruits were well rinsed with distilled water, and the sliced soft flesh and the peel samples were oven-dried (LABOTEC, South Africa) at $40^{\circ} \mathrm{C}$ for 72 hours, after which the dried samples were pulverised using a food blender (Hamilton Beach HBF 500S Series). Another group of $M$. sinensis and $M$. paradisiaca peels $(1000 \mathrm{~g} / \mathrm{L})$ were boiled in distilled water in the water bath (BUCHI B-480) at $80^{\circ} \mathrm{C}$ for 20 minutes. The boiled peel extracts were freeze-dried for 48 hours (Ceramic Filter Core 
Drier CD 052) and stored at $4^{\circ} \mathrm{C}$ until analytical work commenced. $150 \mathrm{~g}$ of the pulverised sample was weighed into three conical flasks, each containing $1,000 \mathrm{~mL}$ of acetone, ethanol, and distilled water solvents. Afterwards, the mixtures were homogenised constantly at $124 \mathrm{rpm}$ on a shaker (Lasec Stuart Orbital Shaker SSL1) for 48 hours. The solvent mixtures were then pressure-filtered through the Whatman filter paper (No 1, $25 \mathrm{~mm}$ ) in a Buchner funnel set-up on the vacuum pump. The acetone and ethanol filtrates were then concentrated further to obtain crude extracts using a rotary evaporator (LABOROTA 4000 Heidolph) at $56^{\circ} \mathrm{C}$ and $78^{\circ} \mathrm{C}$ [20-22] boiling points, respectively, while the aqueous filtrates were chilled in a refrigerant chiller (PolyScience AD15R-40-A12E, USA) at $-40^{\circ} \mathrm{C}$ and concentrated to dry form using the freeze dryer for 48 hours (Ceramic Filter Core Drier CD 052). Water (aqueous) and ethanol extracts were prime organic solvent options since the medium of cooking and preparation of herbal medicines are infusion or decoction using water or alcohol, with acetone chosen because of its extractive ability for hydrophilic and lipophilic plant components. The extraction yields of the three solvents for the fruit compartments of M. sinensis and M. paradisiaca were evaluated and recorded. The extracts were stored at $4^{\circ} \mathrm{C}$ until further analysis.

\subsection{Phytochemical Profiling}

2.3.1. Total Phenolic Content. Total phenol was determined using Folin-Ciocalteau's reagent by the method described by [23] with slight modifications to the concentration. A $0.5 \mathrm{~mL}$ aliquot of the different extracts $(1 \mathrm{mg}$ sample/mL in methanol) and the gallic acid standard was mixed with $2.5 \mathrm{~mL}$ of $10 \%(\mathrm{v} / \mathrm{v})$ Folin-Ciocalteau's reagent and incubated for five minutes. To the solution, $2 \mathrm{~mL}$ of $7.5 \%(\mathrm{w} / \mathrm{v})$ anhydrous sodium carbonate $\left(\mathrm{Na}_{2} \mathrm{CO}_{3}\right)$ was added. The mixtures were incubated at $40^{\circ} \mathrm{C}$ for 30 minutes (LABOTEC-South Africa). Spectrophotometric measurement of absorbance was taken at $765 \mathrm{~nm}$ (Hewlett Packard VR-3000 PC spectrophotometer). Total phenolic (TP) content (mg GAE/g) was derived from the standard curve equation: $y=8.3093 x-0.0023$, $R^{2}=0.9992$. This was expressed from the formula $y=C V / m$, where $C$ is the total content of phenolic compounds in plant extract in $\mathrm{mg} \mathrm{GAE} / \mathrm{g}, V$ is the volume of plant extract used in the assay in $\mathrm{mL}, m$ is the mass of extract used in the assay in $\mathrm{g}$, and $y$ is the concentration obtained from the standard curve in $\mathrm{mg} / \mathrm{mL}$.

2.3.2. Total Proanthocyanidin Content. This was determined based on the method described by [24] with slight modification. $0.5 \mathrm{~mL}$ of extracts and different concentrations $(0.0625 \mathrm{mg} / \mathrm{mL}$ to $1 \mathrm{mg} / \mathrm{mL})$ of catechin (standard) were dispensed into different test tubes. Then, $3 \mathrm{~mL}$ of vanillinmethanol $(4 \% \mathrm{w} / \mathrm{v})$ and $1.5 \mathrm{~mL}$ of hydrochloric acid were added. The mixture was then vortexed and left to stand for 15 minutes at room temperature. The absorbance was spectrophotometrically measured at $500 \mathrm{~nm}$ (UV-3000 PC spectrophotometer). Total proanthocyanidin (TPR) content was evaluated using the equation of the calibration curve: $y=1.1493 x+0.0334, R^{2}=0.9839$, and it was expressed as $\mathrm{mg}$ catechin equivalent (CE)/g using the formula, $C=c V / m$, where $C$ is the total proanthocyanidin content in plant extract in $\mathrm{mg} \mathrm{CE} / \mathrm{g}, c$ is the concentration obtained from the standard curve $(\mathrm{mg} / \mathrm{mL}), V$ is the volume of plant extract used $(\mathrm{mL}), m$ is the mass of extract used $(\mathrm{g})$.

2.3.3. Total Flavonoid Content. Total flavonoid content in the extracts was determined using the colorimetric aluminium chloride method described by [25]. $0.5 \mathrm{~mL}$ of plant extracts and varying concentrations of quercetin standard, ranging from 0.0625 to $1.0 \mathrm{mg} / \mathrm{mL}$, were dispensed into different test tubes. Into tubes were added $2 \mathrm{~mL}$ of distilled water and $0.15 \mathrm{~mL}$ of $5 \%$ sodium nitrite $\left(\mathrm{NaNO}_{2}\right)$, with the solution made to stand for six minutes, after which $0.15 \mathrm{~mL}$ of $10 \%$ aluminium chloride $\left(\mathrm{AlCl}_{3}\right)$ was added and incubated for five minutes. The mixtures were vortexed and incubated at $25^{\circ} \mathrm{C}$ for 15 minutes (LABOTEC, Durban, South Africa), and $1 \mathrm{~mL}$ of $1 \mathrm{M}$ sodium hydroxide was added in each tube. The solution was made up to $5 \mathrm{~mL}$ with the addition of $1.2 \mathrm{~mL}$ distilled water. Absorbance was measured at $420 \mathrm{~nm}$ with a spectrometer. Flavonoid content was quantitatively derived using the equation of the calibration curve:

$$
y=1.1829 x+0.0399, R^{2}=0.9929 \text { with formula } C=\frac{c V}{m},
$$

where $C$ is the total content of flavonoid compound in plant extract (mg QE/g), $c$ is the concentration obtained from standard curve $(\mathrm{mg} / \mathrm{mL}), V$ is the volume of plant extract used $(\mathrm{mL})$, and $m$ is the mass of extract used $(\mathrm{g})$.

2.4. Antioxidant Activity. The antioxidant capacity of the fruits (flesh, peel, and boiled peel extract) of $M$. sinensis and $M$. paradisiaca was evaluated using the DPPH, ABTS, and the FRAP assays.

2.4.1. DPPH Radical Scavenging Activity. DPPH radical scavenging activity was determined as described by [26]. Briefly, $1 \mathrm{~mL}$ of $0.135 \mathrm{mM}$ DPPH radical (prepared with methanol in an opaque bottle) was added to $1.25 \mathrm{~mL}$ of the extracts and standards (gallic acid and rutin), each at varying concentration levels $(0.0025 \mathrm{mg} / \mathrm{mL}$ to $0.01 \mathrm{mg} / \mathrm{mL})$. The solution was vortexed and kept in dark condition at $25^{\circ} \mathrm{C}$ for 30 minutes. Absorbance was spectrophotometrically measured at $517 \mathrm{~nm}$ with methanol as blank. Scavenging activity was evaluated as follows:

$$
\% \mathrm{DPPH} \text { inhibition }=\frac{\mathrm{Abs}(\text { control })-\text { Abs }(6 \text { sample })}{\mathrm{Abs}(\text { control })} \times 100 \% \text {, }
$$

where Abs (control) is the absorbance of DPPH radical + methanol, and Abs (sample) is the absorbance of DPPH radical + sample extract or standard. 
2.4.2. ABTS Radical Scavenging Activity. This was determined as described in [27]. The stock solution of ABTS was prepared by mixing $7 \mathrm{mM}$ ABTS and $2.45 \mathrm{mM}$ potassium persulfate $\left(\mathrm{K}_{2} \mathrm{~S}_{2} \mathrm{O}_{8}\right)(1: 1)$ and was incubated in the dark at $25^{\circ} \mathrm{C}$ for about 18 hours in order to release its radicals $\left(\mathrm{ABTS}^{+}\right)$. The solution was diluted further by the mixture of $1 \mathrm{~mL} \mathrm{ABTS}^{+}$with $50 \mathrm{ml}$ methanol to obtain a working solution (absorbance $0.700 \pm 0.0006$ at $734 \mathrm{~nm}$ ). Plant extracts and rutin standard solution of concentration $(0.005 \mathrm{mg} / \mathrm{mL}-0.08 \mathrm{mg} / \mathrm{mL})$ were reacted with $1 \mathrm{~mL}$ ABTS in a test tube and kept in dark condition for 7 minutes. The absorbance was determined at $734 \mathrm{~nm}$ against methanol (blank):

$$
\% \text { ABTS inhibition }=\frac{\text { Abs }(\text { control })-\text { Abs }(\text { sample })}{\text { Abs }(\text { control })} \times 100 \% \text {, }
$$

where Abs (control) is the absorbance of ABTS radical+methanol and Abs (sample) is the absorbance of ABTS radical +sample extract/standard.

2.4.3. FRAP Assay. The ferric reducing power of $M$. sinensis and $M$. paradisiaca extracts was determined using the method described by [28]. The FRAP reagent was prepared upon the mixture of $2.5 \mathrm{~mL} 0.2 \mathrm{M}$ phosphate buffer reagent $(62.5 \%$ monobasic $+37.5 \%$ dibasic; $\mathrm{pH} 6.6)$ and $2.5 \mathrm{~mL}$ of $1 \%$ potassium ferricyanide $\left(\mathrm{K}_{3} \mathrm{Fe}(\mathrm{CN})_{6}\right) .1 \mathrm{~mL}$ of the standard rutin and plant extracts at varying concentration levels $(0.025 \mathrm{mg} /$ $\mathrm{mL}-0.1 \mathrm{mg} / \mathrm{mL}$ ) were added to the FRAP solution. This mixture was incubated in a water bath (BUCHI B-480) at $50^{\circ} \mathrm{C}$ for 20 minutes. Afterwards, $2.5 \mathrm{~mL}$ of $10 \%$ trichloroacetic acid (TCA) was added and the mixture was centrifuged at $300 \mathrm{rpm}$ for 10 minutes; then, $0.5 \mathrm{~mL} 0.1 \%$ iron (III) chloride $\left(\mathrm{FeCl}_{3}\right), 2.5 \mathrm{~mL}$ of distilled water, and the $8.5 \mathrm{~mL}$ supernatant from the centrifuged solution $(1: 5: 5)$ were mixed and incubated for 10 minutes, at room temperature. The ferric reducing ability of plant extracts (mg/g Fe (II) equivalent) was measured at $700 \mathrm{~nm}$ against the methanol blank. Ferric reducing power (iron (II)) was quantitatively derived using the following equation:

$$
y=21.277 x+0.6385, R^{2}=0.9988
$$

and $C=c \times V / m$, where $C$ is the Fe (II) content of the FRAP solution in the plant extract (RE/g), $c$ is the concentration of standard obtained from the standard curve $(\mathrm{mg} / \mathrm{mL}), V$ is the volume of plant extract used $(\mathrm{mL})$, and $m$ is the mass of extract used (g).

2.5. Statistical Analysis. Data obtained from this study were expressed as mean \pm standard deviation, based on triplicate experimentation. The statistical analysis carried out was done using the one-way analysis of variance (ANOVA) and mean separation by Fischer's LSD on the MINITAB statistical package.

\section{Results and Discussion}

Table 1 shows the extraction yield of the solvents from the fruit compartments of $M$. sinensis and $M$. paradisiaca. The aqueous and ethanol extracts had the highest and lowest yields, respectively, across the flesh and peel compartments of $M$. sinensis and $M$. paradisiaca. In this regard, a consistent yield trend in the order aqueous $>$ ethanol $>$ acetone was observed. On the other hand, boiled peel extracts (Be and $\mathrm{Pe}$ ) had the lowest yields in their respective aqueous extract groups of $M$. sinensis and $M$. paradisiaca.

3.1. Phytochemicals. Table 2 shows total phenol, proanthocyanidin, and flavonoid contents of the acetone, aqueous, and ethanol solvent extractions of $M$. sinensis and $M$. paradisiaca fruits. In $M$. sinensis, the ethanol extract of the peel contained the highest phenol $(157.19 \pm 4.76 \mathrm{mg} \mathrm{GAE} / \mathrm{g})$, while the acetone extract of the peel also contained the highest proanthocyanidin $(619.39 \pm 21.88 \mathrm{mg} \mathrm{CE} / \mathrm{g})$ and flavonoid $(734.52 \pm 32.55 \mathrm{mg} \mathrm{QE} /$ g) contents. Similarly, in $M$. paradisiaca, the acetone extract of the peel contained higher phenol $(136.87 \pm 5.69 \mathrm{mg}$ GAE/g) and proanthocyanidin $(530.06 \pm 53.51 \mathrm{mg} \mathrm{CE} / \mathrm{g})$ contents, while the acetone extract of the flesh contained the higher flavonoid (777.35 $\pm 150.95 \mathrm{mg} \mathrm{QE} / \mathrm{g}$ ) content. The boiled peel extract sample of $M$. sinensis contained the highest phenol (97.05 $\pm 3.60 \mathrm{mg} \mathrm{GAE} / \mathrm{g})$ and flavonoid (418.35 $\pm 427.26 \mathrm{mg} \mathrm{QE} /$ g) contents amongst the aqueous extractions, just as the boiled peel extract sample in $M$. paradisiaca had the highest phenol $(114.23 \pm 4.58 \mathrm{mg} \mathrm{GAE} / \mathrm{g})$ and flavonoid $(83.58 \pm 34.16 \mathrm{mg} \mathrm{QE} / \mathrm{g})$ contents. On the other hand, $M$. paradisiaca acetone extracts had the highest phenol $(136.87 \pm 5.59 \mathrm{mg}$ GAE/g) and proanthocyanidin $(530.06 \pm 53.51 \mathrm{mg} \mathrm{CE} / \mathrm{g})$ in the peel with the highest flavonoid (777.35 $\pm 150.95 \mathrm{mg} \mathrm{QE} / \mathrm{g}$ ) in the flesh. Summarily, polyphenolic constituent was consistently predominant in the organic (acetone and ethanol) solvent extractions of $M$. sinensis and $M$. paradisiaca flesh and peel as evidenced by the extremely low or absent proanthocyanidin levels in all the aqueous extracts of $M$. sinensis and $M$. paradisiaca and for flavonoid in the aqueous extracts of $M$. sinensis flesh and peel and $M$. paradisiaca flesh as well.

\subsection{Antioxidant Activity of the Acetone, Ethanol, and Aqueous Extracts of $M$. sinensis and M. paradisiaca Fruit Compartments}

3.2.1. DPPH. The percentage DPPH radical inhibitory activity of the $M$. sinensis extracts including standards (Table 3) was gallic acid $>$ rutin $>$ banana peel acetone extract $>$ banana flesh ethanol extract $>$ banana boiled peel extrac$\mathrm{t}>$ banana peel ethanol extract $>$ banana flesh acetone extract $>$ banana flesh aqueous extract $>$ banana peel aqueous extract at the highest concentration $(0.01 \mathrm{mg} / \mathrm{mL})$.

For $M$. paradisiaca: gallic acid > rutin > plantain boiled peel extract $>$ plantain peel aqueous extract $>$ plantain peel acetone extract $>$ plantain flesh ethanol extract $>$ plantain peel ethanol extract $>$ plantain flesh acetone extrac$\mathrm{t}>$ plantain flesh aqueous extract at the highest concentration $(0.01 \mathrm{mg} / \mathrm{mL})$.

Table 3 shows that the standard drugs (gallic acid $(84.03 \pm 0.002 \%)$ and rutin $(64.12 \pm 0.01 \%))$ and all aqueous and ethanol extracts of the flesh and peel in $M$. sinensis and $M$. paradisiaca had peak antioxidant activity at the highest 
TABLE 1: Extraction yield of solvents.

\begin{tabular}{lcc}
\hline Solvents & Fruit compartments & Extraction yield (\%) \\
\hline Aqueous & $\mathrm{Bf}$ & 7.13 \\
Aqueous & $\mathrm{Bp}$ & 7.00 \\
Aqueous & $\mathrm{Be}$ & 6.67 \\
Aqueous & $\mathrm{Pf}$ & 7.86 \\
Aqueous & $\mathrm{Pp}$ & 7.67 \\
Aqueous & $\mathrm{Pe}$ & 7.33 \\
Acetone & $\mathrm{Bf}$ & 1.86 \\
Acetone & $\mathrm{Bp}$ & 1.00 \\
Acetone & $\mathrm{Pf}$ & 2.00 \\
Acetone & $\mathrm{Pp}$ & 1.33 \\
Ethanol & $\mathrm{Bf}$ & 2.67 \\
Ethanol & $\mathrm{Bp}$ & 2.00 \\
Ethanol & $\mathrm{Pf}$ & 4.00 \\
Ethanol & $\mathrm{Pp}$ & 3.13 \\
\hline
\end{tabular}

B: banana (M. sinensis); P: plantain (M. paradisiaca); f: flesh; p: peel; e: boiled peel extract.

TABLE 2: Total polyphenolic contents of extracts.

\begin{tabular}{|c|c|c|c|c|}
\hline & Samples & $\begin{array}{c}\text { Phenol (mg GAE/g) } \\
R^{2}=0.9992 \\
\end{array}$ & $\begin{array}{c}\text { Proanthocyanidin (mg CE } / \mathrm{g}) \\
R^{2}=0.9839\end{array}$ & $\begin{array}{c}\text { Flavonoid (mg QE/g) } \\
R^{2}=0.9929\end{array}$ \\
\hline \multirow{4}{*}{ Acetone } & Banana flesh & $119.05 \pm 5.80^{\mathrm{cd}}$ & $337.48 \pm 13.16^{\mathrm{de}}$ & $602.64 \pm 3.65^{\mathrm{ab}}$ \\
\hline & Banana peel & $128.20 \pm 5.73^{\mathrm{bc}}$ & $619.39 \pm 21.88^{\mathrm{a}}$ & $734.52 \pm 32.55^{\mathrm{a}}$ \\
\hline & Plantain flesh & $114.80 \pm 1.49^{\mathrm{de}}$ & $436.09 \pm 36.44^{\mathrm{c}}$ & $777.35 \pm 150.95^{\mathrm{a}}$ \\
\hline & Plantain peel & $136.87 \pm 5.69^{\mathrm{b}}$ & $530.06 \pm 53.51^{\mathrm{b}}$ & $750.87 \pm 55.61^{\mathrm{a}}$ \\
\hline \multirow{6}{*}{ Aqueous } & Banana flesh & $43.83 \pm 1.13^{\mathrm{h}}$ & $-48.84 \pm 8.19^{g}$ & $-59.57 \pm 3.01^{\mathrm{e}}$ \\
\hline & Banana peel & $47.68 \pm 2.14^{\mathrm{h}}$ & $-55.22 \pm 1.88^{\mathrm{g}}$ & $-42.01 \pm 1.19^{\mathrm{de}}$ \\
\hline & $\begin{array}{c}\text { Banana boiled peel } \\
\text { extract }\end{array}$ & $97.05 \pm 3.60^{f}$ & $-11.14 \pm 2.46^{\mathrm{g}}$ & $418.35 \pm 427.26^{\mathrm{bc}}$ \\
\hline & Plantain peel & $83.32 \pm 4.38^{\mathrm{g}}$ & $-23.90 \pm 8.90^{\mathrm{g}}$ & $17.64 \pm 3.01^{\mathrm{de}}$ \\
\hline & Plantain flesh & $17.41 \pm 0.17^{\mathrm{i}}$ & $-79.00 \pm 8.52^{\mathrm{g}}$ & $-55.62 \pm 2.07^{\mathrm{e}}$ \\
\hline & $\begin{array}{c}\text { Plantain boiled peel } \\
\text { extract }\end{array}$ & $114.23 \pm 4.58^{\mathrm{de}}$ & $-33.18 \pm 1.88^{\mathrm{g}}$ & $83.58 \pm 34.16^{\mathrm{de}}$ \\
\hline \multirow{4}{*}{ Ethanol } & Banana flesh & $107.41 \pm 4.67^{\mathrm{ef}}$ & $274.83 \pm 16.38^{\mathrm{e}}$ & $501.20 \pm 50.95^{\mathrm{abc}}$ \\
\hline & Banana peel & $157.19 \pm 4.76^{\mathrm{a}}$ & $446.53 \pm 87.39^{c}$ & $582.35 \pm 0.69^{\mathrm{ab}}$ \\
\hline & Plantain flesh & $75.14 \pm 0.55^{\mathrm{g}}$ & $68.33 \pm 7.42^{\mathrm{f}}$ & $249.27 \pm 13.33^{\mathrm{cd}}$ \\
\hline & Plantain peel & $133.42 \pm 8.18^{\mathrm{b}}$ & $405.35 \pm 18.51^{\mathrm{cd}}$ & $641.53 \pm 14.76^{\mathrm{ab}}$ \\
\hline
\end{tabular}

Banana (M. sinensis); plantain (M. paradisiaca). Significantly different means $(p \leq 0.05)$ not sharing the same letter.

concentration gradient $(0.01 \mathrm{mg} / \mathrm{mL})$. A similar pattern existed in the acetone extracts of $M$. sinensis flesh $(3.93 \pm 0.02 \%)$ and peel $(11.17 \pm 0.002 \%)$ and $M$. paradisiaca peel $(11.01 \pm 0.002 \%)$.

3.2.2. FRAP. Table 4 shows that ferric reducing power for banana group was in the order rutin $>$ banana peel ethanol extract $>$ banana peel aqueous extract $>$ banana flesh ethanol extract $>$ banana boiled peel extract $>$ banana flesh acetone extract $>$ banana flesh aqueous extract $>$ banana peel acetone extract at the highest concentration $(0.1 \mathrm{mg} / \mathrm{mL})$.

The order for plantain was rutin $>$ plantain peel acetone extract $>$ plantain flesh ethanol extract $>$ plantain peel ethanol extract $>$ plantain flesh acetone extract $>$ plantain boiled peel extract $>$ plantain flesh aqueous extract $>$ plantain peel aqueous extract at the highest concentration $(0.1 \mathrm{mg} / \mathrm{mL})$.

At the highest concentration gradient used $(0.1 \mathrm{mg} / \mathrm{mL})$, ethanol extracts of $M$. sinensis flesh $(145.27 \pm 1.94 \mathrm{mg} / \mathrm{g})$ and peel $(154.60 \pm 1.47 \mathrm{mg} / \mathrm{g})$ and $M$. paradisiaca flesh $(153.81 \pm 1.55 \mathrm{mg} / \mathrm{g})$ had the highest ferric reducing power, while the acetone extract of $M$. paradisiaca peel $(155.56 \pm 1.81 \mathrm{mg} / \mathrm{g})$ had the greatest ferric reducing power.

3.2.3. ABTS. The ABTS radical scavenging activity of extracts shows that gallic acid had a generally higher scavenging activity than the rutin. The percentage ABTS inhibitory activity of the banana flesh and peel and peel extracts as well as the standards was of the following order: rutin $>$ banana boiled peel extract $>$ banana peel aqueous extract $>$ banana peel ethanol $>$ banana peel acetone extract $>$ banana flesh acetone extract $>$ banana flesh ethanol extract $>$ banana flesh aqueous extract at the highest concentration $(0.08 \mathrm{mg} / \mathrm{L})$.

On the other hand, in plantain, the ABTS inhibitory activity order was rutin $>$ plantain boiled peel extrac$\mathrm{t}>$ plantain peel aqueous extract $>$ plantain peel ethanol 
TABLE 3: DPPH radical scavenging activity (\%) of extracts and standards.

\begin{tabular}{|c|c|c|c|c|}
\hline \multicolumn{5}{|c|}{ Concentration $(\mathrm{mg} / \mathrm{mL})$} \\
\hline Solvent & Sample & 0.01 & 0.005 & 0.0025 \\
\hline \multirow{4}{*}{ Acetone } & $\mathrm{Bf}$ & $3.93 \pm 0.02^{\mathrm{cd}}$ & $1.89 \pm 0.01^{\mathrm{cd}}$ & $1.49 \pm 0.01^{\mathrm{cd}}$ \\
\hline & $\mathrm{Bp}$ & $11.17 \pm 0.002^{\mathrm{cd}}$ & $8.73 \pm 0.00^{\mathrm{cd}}$ & $8.50 \pm 0.00^{\mathrm{cd}}$ \\
\hline & $\mathrm{Pf}$ & $3.85 \pm 0.004^{\mathrm{cd}}$ & $3.70 \pm 0.01^{\mathrm{cd}}$ & $4.33 \pm 0.001^{\mathrm{cd}}$ \\
\hline & $\mathrm{Pp}$ & $11.01 \pm 0.002^{\mathrm{cd}}$ & $2.28 \pm 0.001^{\mathrm{cd}}$ & $5.90 \pm 0.003^{\mathrm{cd}}$ \\
\hline \multirow{6}{*}{ Aqueous } & $\mathrm{Bf}$ & $0.55 \pm 0.003^{\mathrm{d}}$ & $-11.96 \pm 0.07^{\mathrm{d}}$ & $-0.47 \pm 0.004^{\mathrm{d}}$ \\
\hline & $\mathrm{Bp}$ & $0.08 \pm 0.01^{\mathrm{cd}}$ & $-1.43 \pm 0.01^{\mathrm{cd}}$ & $-3.85 \pm 0.005^{\mathrm{cd}}$ \\
\hline & $\mathrm{Be}$ & $8.42 \pm 0.01^{\mathrm{cd}}$ & $3.07 \pm 0.005^{\mathrm{cd}}$ & $-0.16 \pm 0.01^{\mathrm{cd}}$ \\
\hline & $\mathrm{Pf}$ & $0.24 \pm 0.005^{\mathrm{cd}}$ & $-0.16 \pm 0.001^{\mathrm{cd}}$ & $-1.18 \pm 0.005^{\mathrm{cd}}$ \\
\hline & $\mathrm{Pp}$ & $11.09 \pm 0.03^{\mathrm{cd}}$ & $1.73 \pm 0.005^{\mathrm{cd}}$ & $2.83 \pm 0.004^{\mathrm{cd}}$ \\
\hline & $\mathrm{Pe}$ & $17.54 \pm 0.003^{c}$ & $9.28 \pm 0.004^{c}$ & $8.26 \pm 0.01^{\mathrm{c}}$ \\
\hline \multirow{6}{*}{ Ethanol } & $\mathrm{Bf}$ & $9.91 \pm 0.001^{\mathrm{cd}}$ & $7.47 \pm 0.002^{\mathrm{cd}}$ & $6.84 \pm 0.002^{\mathrm{cd}}$ \\
\hline & $\mathrm{Bp}$ & $5.27 \pm 0.002^{\mathrm{cd}}$ & $-0.47 \pm 0.004^{\mathrm{cd}}$ & $-3.07 \pm 0.01^{\mathrm{cd}}$ \\
\hline & $\mathrm{Pf}$ & $10.46 \pm 0.001^{\mathrm{cd}}$ & $7.71 \pm 0.004^{\mathrm{cd}}$ & $5.66 \pm 0.003^{\mathrm{cd}}$ \\
\hline & $\mathrm{Pp}$ & $6.61 \pm 0.02^{\mathrm{cd}}$ & $3.54 \pm 0.01^{\mathrm{cd}}$ & $-0.24 \pm 0.005^{\mathrm{cd}}$ \\
\hline & Gallic acid & $84.03 \pm 0.002^{\mathrm{a}}$ & $70.81 \pm 0.02^{\mathrm{a}}$ & $51.38 \pm 0.001^{\mathrm{a}}$ \\
\hline & Rutin & $64.12 \pm 0.01^{\mathrm{b}}$ & $35.09 \pm 0.005^{\mathrm{b}}$ & $15.42 \pm 0003^{\mathrm{b}}$ \\
\hline
\end{tabular}

B: banana; P: plantain; f: flesh; p: peel; e: boiled peel extract. Banana (M. sinensis); plantain (M. paradisiaca).

TABLE 4: Ferric reducing power (mg RE/g) of the extracts and standard.

\begin{tabular}{|c|c|c|c|c|}
\hline \multicolumn{5}{|c|}{ Concentration $(\mathrm{mg} / \mathrm{mL})$} \\
\hline \multicolumn{2}{|c|}{ Sample } & 0.1 & 0.05 & 0.025 \\
\hline \multirow{4}{*}{ Acetone } & $\mathrm{Bf}$ & $142.76 \pm 2.02^{\mathrm{ab}}$ & $147.09 \pm 1.44^{\mathrm{ab}}$ & $144.56 \pm 1.32^{\mathrm{ab}}$ \\
\hline & Bp & $138.42 \pm 1.46^{\mathrm{ab}}$ & $148.71 \pm 2.76^{\mathrm{ab}}$ & $137.13 \pm 0.64^{\mathrm{ab}}$ \\
\hline & $\mathrm{Pf}$ & $145.38 \pm 3.25^{\mathrm{ab}}$ & $140.09 \pm 0.89^{\mathrm{ab}}$ & $137.27 \pm 3.36^{\mathrm{ab}}$ \\
\hline & $\mathrm{Pp}$ & $155.56 \pm 1.81^{\mathrm{a}}$ & $153.53 \pm 1.42^{\mathrm{a}}$ & $150.45 \pm 1.38^{\mathrm{a}}$ \\
\hline \multirow{4}{*}{ Ethanol } & $\mathrm{Bf}$ & $145.27 \pm 1.94^{\mathrm{ab}}$ & $146.09 \pm 2.19^{\mathrm{ab}}$ & $141.22 \pm 2.02^{\mathrm{ab}}$ \\
\hline & Bp & $154.60 \pm 1.47^{\mathrm{a}}$ & $154.15 \pm 1.10^{\mathrm{a}}$ & $139.58 \pm 5.64^{\mathrm{a}}$ \\
\hline & $\mathrm{Pf}$ & $153.81 \pm 1.55^{\mathrm{a}}$ & $150.82 \pm 0.87^{\mathrm{a}}$ & $143.82 \pm 3.37^{\mathrm{a}}$ \\
\hline & $\mathrm{Pp}$ & $146.48 \pm 1.40^{\mathrm{ab}}$ & $140.84 \pm 2.13^{\mathrm{ab}}$ & $148.75 \pm 3.22^{\mathrm{ab}}$ \\
\hline \multirow{7}{*}{ Aqueous } & $\mathrm{Bf}$ & $141.55 \pm 3.05^{\mathrm{ab}}$ & $138.35 \pm 0.78^{\mathrm{ab}}$ & $144.53 \pm 0.92^{\mathrm{ab}}$ \\
\hline & $\mathrm{Bp}$ & $147.10 \pm 1.87^{\mathrm{ab}}$ & $140.32 \pm 2.48^{\mathrm{ab}}$ & $135.48 \pm 3.47^{\mathrm{ab}}$ \\
\hline & $\mathrm{Be}$ & $144.40 \pm 2.40^{\mathrm{ab}}$ & $137.92 \pm 2.11^{\mathrm{ab}}$ & $146.07 \pm 2.08^{\mathrm{ab}}$ \\
\hline & Pf & $143.35 \pm 1.91^{\mathrm{ab}}$ & $139.42 \pm 4.19^{\mathrm{ab}}$ & $135.79 \pm 1.48^{\mathrm{ab}}$ \\
\hline & $\mathrm{Pp}$ & $137.71 \pm 1.83^{\mathrm{ab}}$ & $137.60 \pm 2.60^{\mathrm{ab}}$ & $139.09 \pm 2.61^{\mathrm{ab}}$ \\
\hline & $\mathrm{Pe}$ & $144.04 \pm 0.58^{\mathrm{ab}}$ & $138.33 \pm 2.05^{\mathrm{ab}}$ & $143.76 \pm 5.02^{\mathrm{ab}}$ \\
\hline & Rutin & $195.95 \pm 2.18^{\mathrm{b}}$ & $101.44 \pm 0.99^{\mathrm{b}}$ & $47.25 \pm 0.45^{\mathrm{b}}$ \\
\hline
\end{tabular}

B: banana; P: plantain; f: flesh; p: peel; e: boiled peel extract. Significantly different means $(p \leq 0.05)$ not sharing the same letter. Banana ( $M$. sinensis); plantain (M. paradisiaca).

extract $>$ plantain peel acetone extract $>$ plantain flesh ethanol extract $>$ plantain flesh acetone extract $>$ plantain flesh aqueous extract at the highest concentration level $(0.08 \mathrm{mg} / \mathrm{mL})$.

Table 5 shows that the rutin standard $(99.10 \pm 0.0004 \%)$ and acetone and ethanol extracts of $M$. sinensis and $M$. paradisiaca flesh and peel had the peak ABTS radical scavenging activity at the highest concentration gradient $(0.08 \mathrm{mg} / \mathrm{mL})$. However, amongst the aqueous extracts, all except $M$. sinensis and $M$. paradisiaca flesh had peak activity at the highest concentration gradient. $M$. sinensis flesh had its peak activity at $0.04 \mathrm{mg} / \mathrm{mL}$, while $M$. paradisiaca had its own peak activity at $0.01 \mathrm{mg} / \mathrm{mL}$ concentration gradient.
Table 6 shows that peak activity in the plant extracts was observed in the acetone extract of $M$. paradisiaca flesh $(<0.0025 \mathrm{mg} / \mathrm{mL})$. However, ethanol and aqueous extracts of the flesh and peel, including the peel extract of $M$. sinensis and M. paradisiaca, had $\mathrm{IC}_{50}$ values above the highest concentration $(0.01 \mathrm{mg} / \mathrm{mL})$. From the $\mathrm{IC}_{50}, \mathrm{ABTS}$ had its peak activity in the peel extract of $M$. sinensis $(0.03 \mathrm{mg} / \mathrm{mL})$, followed by the aqueous extract of $M$. sinensis peel $(0.04 \mathrm{mg} /$ $\mathrm{mL}$ ). On the other hand, $M$. paradisiaca had a joint peak activity in aqueous extracts of the peel and peel extract $(0.04 \mathrm{mg} / \mathrm{mL})$ (Table 6$)$. The negative values observed in acetone and aqueous extracts of $M$. paradisiaca flesh $(\mathrm{DPPH}$ and ABTS) could suggest the preoxidant activity at particular concentration levels and potent scavenging capacity as well. 
TABLE 5: ABTS radical inhibition activity (\%) by extracts and standard.

\begin{tabular}{|c|c|c|c|c|c|c|}
\hline Solvent & Sample & $0.08 \mathrm{mg} / \mathrm{mL}$ & $0.04 \mathrm{mg} / \mathrm{mL}$ & $0.02 \mathrm{mg} / \mathrm{mL}$ & $0.01 \mathrm{mg} / \mathrm{mL}$ & $0.005 \mathrm{mg} / \mathrm{mL}$ \\
\hline \multirow{4}{*}{ Acetone } & $\mathrm{Bf}$ & $37.56 \pm 0.003^{\mathrm{bcde}}$ & $30.09 \pm 0.002^{\text {bcde }}$ & $25.17 \pm 0.004^{\text {bcde }}$ & $24.38 \pm 0.004^{\text {bcde }}$ & $21.93 \pm 0.004^{\text {bcde }}$ \\
\hline & $\mathrm{Bp}$ & $42.08 \pm 0.001^{\text {bcde }}$ & $28.12 \pm 0.01^{\text {bcde }}$ & $24.29 \pm 0.004^{\text {bcde }}$ & $23.89 \pm 0.01^{\text {bcde }}$ & $23.99 \pm 0.004^{\text {bcde }}$ \\
\hline & $\mathrm{Pf}$ & $29.20 \pm 0.01^{\mathrm{de}}$ & $24.29 \pm 0.005^{\mathrm{de}}$ & $15.34 \pm 0.01^{\mathrm{de}}$ & $15.53 \pm 0.004^{\mathrm{de}}$ & $11.80 \pm 0.01^{\mathrm{de}}$ \\
\hline & $\mathrm{Pp}$ & $49.65 \pm 0.004^{\mathrm{abcd}}$ & $34.71 \pm 0.001^{\mathrm{abcd}}$ & $28.71 \pm 0.003^{\mathrm{abcd}}$ & $24.29 \pm 0.004^{\mathrm{abcd}}$ & $23.70 \pm 0.005^{\mathrm{abcd}}$ \\
\hline \multirow{6}{*}{ Aqueous } & $\mathrm{Bf}$ & $24.19 \pm 0.003^{\mathrm{cde}}$ & $24.58 \pm 0.002^{\text {cde }}$ & $19.66 \pm 0.001^{\mathrm{cde}}$ & $18.19 \pm 0.00^{\text {cde }}$ & $17.80 \pm 0.002^{\text {cde }}$ \\
\hline & Bp & $74.93 \pm 0.004^{\mathrm{abc}}$ & $47.79 \pm 0.004^{\mathrm{abc}}$ & $31.66 \pm 0.006^{\mathrm{abc}}$ & $23.20 \pm 0.001^{\mathrm{abc}}$ & $20.06 \pm 0.004^{\mathrm{abc}}$ \\
\hline & $\mathrm{Be}$ & $87.90 \pm 0.01^{\mathrm{a}}$ & $57.62 \pm 0.01^{\mathrm{a}}$ & $37.95 \pm 0.01^{\mathrm{a}}$ & $26.06 \pm 0.003^{\mathrm{a}}$ & $31.37 \pm 0.003^{\mathrm{a}}$ \\
\hline & Pf & $9.64 \pm 0.01^{\mathrm{e}}$ & $11.40 \pm 0.005^{\mathrm{e}}$ & $11.21 \pm 0.004^{\mathrm{e}}$ & $13.86 \pm 0.001^{\mathrm{e}}$ & $11.99 \pm 0.01^{\mathrm{e}}$ \\
\hline & $\mathrm{Pp}$ & $54.28 \pm 0.002^{\mathrm{abcde}}$ & $51.72 \pm 0.005^{\mathrm{abcde}}$ & $24.19 \pm 0.01^{\mathrm{abcde}}$ & $20.25 \pm 0.01^{\text {abcde }}$ & $0.69 \pm 0.004^{\text {abcde }}$ \\
\hline & $\mathrm{Pe}$ & $90.17 \pm 0.04^{\mathrm{ab}}$ & $47.10 \pm 0.001^{\mathrm{ab}}$ & $38.54 \pm 0.004^{\mathrm{ab}}$ & $19.47 \pm 0.01^{\mathrm{ab}}$ & $19.07 \pm 0.004^{\mathrm{ab}}$ \\
\hline \multirow{5}{*}{ Ethanol } & $\mathrm{Bf}$ & $33.82 \pm 0.004^{\text {bcde }}$ & $24.19 \pm 0.00^{\text {bcde }}$ & $24.88 \pm 0.00^{\text {bcde }}$ & $21.73 \pm 0.004^{\text {bcde }}$ & $23.01 \pm 0.004^{\text {bcde }}$ \\
\hline & Bp & $60.27 \pm 0.003^{\mathrm{abcd}}$ & $42.48 \pm 0.002^{\mathrm{abcd}}$ & $31.86 \pm 0.004^{\mathrm{abcd}}$ & $24.19 \pm 0.01^{\mathrm{abcd}}$ & $26.06 \pm 0.004^{\mathrm{abcd}}$ \\
\hline & $\mathrm{Pf}$ & $30.28 \pm 0.003^{\mathrm{bcde}}$ & $27.04 \pm 0.003^{\text {bcde }}$ & $22.42 \pm 0.001^{\mathrm{bcde}}$ & $21.04 \pm 0.01^{\text {bcde }}$ & $19.37 \pm 0.003^{\text {bcde }}$ \\
\hline & Pp & $53.10 \pm 0.003^{\mathrm{bcde}}$ & $31.66 \pm 0.003^{\text {bcde }}$ & $19.37 \pm 0.002^{\text {bcde }}$ & $15.83 \pm 0.003^{\mathrm{bcde}}$ & $13.37 \pm 0.001^{\text {bcde }}$ \\
\hline & Rutin & $99.10 \pm 0.0004^{\mathrm{a}}$ & $80.33 \pm 0.01^{\mathrm{a}}$ & $31.37 \pm 0.002^{\mathrm{a}}$ & $18.68 \pm 0.01^{\mathrm{a}}$ & $11.70 \pm 0.002^{\mathrm{a}}$ \\
\hline
\end{tabular}

TABle 6: $\mathrm{IC}_{50}$ values $(\mathrm{mg} / \mathrm{mL})$ of extracts and standards.

\begin{tabular}{|c|c|c|c|c|c|}
\hline & \multirow{2}{*}{ Extract/standard } & \multicolumn{2}{|c|}{ DPPH } & \multicolumn{2}{|c|}{ ABTS } \\
\hline & & $\mathrm{IC}_{50}$ & $R^{2}$ & $\mathrm{IC}_{50}$ & $R^{2}$ \\
\hline \multirow{4}{*}{ Acetone } & Banana flesh & 0.08 & 0.8941 & 0.14 & 0.9904 \\
\hline & Banana peel & 0.11 & 0.937 & 0.12 & 0.9377 \\
\hline & Plantain flesh & -0.92 & 0.3324 & 0.17 & 0.9243 \\
\hline & Plantain peel & 0.06 & 0.5268 & 0.08 & 0.9971 \\
\hline \multirow{4}{*}{ Ethanol } & Banana flesh & 0.10 & 0.9811 & 0.20 & 0.8756 \\
\hline & Banana peel & 0.05 & 0.9994 & 0.06 & 0.9873 \\
\hline & Plantain flesh & 0.07 & 0.989 & 0.21 & 0.9457 \\
\hline & Plantain peel & 0.06 & 0.9389 & 0.07 & 0.9976 \\
\hline \multirow{8}{*}{ Aqueous } & Banana flesh & 0.12 & 0.068 & 0.35 & 0.747 \\
\hline & Banana peel & 0.11 & 0.8991 & 0.04 & 0.998 \\
\hline & Banana boiled peel extract & 0.05 & 0.9977 & 0.03 & 0.9802 \\
\hline & Plantain flesh & 0.30 & 0.8176 & -0.91 & 0.6616 \\
\hline & Plantain peel & 0.04 & 0.8176 & 0.06 & 0.7657 \\
\hline & Plantain boiled peel extract & 0.03 & 0.9468 & 0.04 & 0.9795 \\
\hline & Gallic acid & 0.001 & 0.9129 & - & - \\
\hline & Rutin & 0.01 & 0.9937 & 0.03 & 0.9058 \\
\hline
\end{tabular}

\section{Correlation between Phytochemical Constituents and Antioxidant Activity of M. sinensis and M. paradisiaca Flesh and Peel Compartments}

Pearson's coefficient was used to analyse the relationship existing between the pharmacological variables (total phenol, proanthocyanidin, and flavonoid) and antioxidant capacity (DPPH, ABTS, and FRAP) of the flesh and peel compartments of $M$. sinensis and $M$. paradisiaca fruits.

Table 7 shows a negative correlation between the respective phenolic, proanthocyanidin, flavonoid constituents, and the $\mathrm{IC}_{50} \mathrm{DPPH}$ antioxidant capacity in $M$. sinensis flesh $(r=-0.999 ;-0.938$ and -0.998$), M$. sinensis peel $(r=-0.123$; -0.708 and -0.664$)$, and M. paradisiaca flesh $(r=-0.947$; -0.998 and -0.979 ), while the $\mathrm{IC}_{50} \mathrm{DPPH}$ antioxidant capacity of $M$. paradisiaca peel positively correlated with the proanthocyanidin $(r=0.43)$ and flavonoid $(r=0.323)$ constituents.

There was a negative correlation observed between the phenolic, proanthocyanidin, and flavonoid constituents and the $\mathrm{IC}_{50}$ ABTS antioxidant capacity of $M$. sinensis flesh $(r=-0.962 ;-0.994$ and -0.955$)$, while positive correlation exists between the respective phytochemical constituents and the $\mathrm{IC}_{50}$ ABTS antioxidant capacity in $M$. sinensis peel $(r=0.919 ; 0.483$ and 0.534$)$, $M$. paradisiaca flesh $(r=0.840 ; 0.664$ and 0.768$)$, and $M$. paradisiaca peel $(r=0.203 ; 0.850$ and 0.753$)$ (Table 7$)$.

There was negative correlation between the phenolic, proanthocyanidin, and flavonoid constituents and the $\mathrm{IC}_{50}$ FRAP antioxidant capacity in the flesh of $M$. sinensis $(r=-0.092$; -0.462 and -0.067 ), while the peel correlated positively $(r=0.799 ; 0.260$ and 0.318$)$. Conversely, in M. paradisiaca, the $\mathrm{IC}_{50}$ FRAP antioxidant capacity of the flesh correlated positively with the phenolic, proanthocyanidin, and flavonoid constituents $(r=0.690 ; 0.471$ and 0.597$)$, while the peel showed negative correlation $(r=-0.866 ;-0.946$ and -0.986$)$ (Table 7).

Medicinal plants are widely used for their therapeutic potential which they derive from their array of bioactive principles. They are key in frontiers of natural products, green chemistry, and drug development [29]. 
TABle 7: Correlation between phytochemical constituents and antioxidant activity of $M$. sinensis and M. paradisiaca flesh and peel compartments.

\begin{tabular}{|c|c|c|c|}
\hline \multicolumn{4}{|c|}{ Pearson's coefficient $(r)$} \\
\hline Antioxidant parameters & Total phenol & Total proanthocyanidin & Total flavonoid \\
\hline $\mathrm{IC}_{50} \mathrm{DPPH} \mathrm{Bf}$ & $-0.999^{*}$ & $-0.938^{\mathrm{ns}}$ & $-0.998^{*}$ \\
\hline $\mathrm{IC}_{50} \mathrm{DPPH} \mathrm{Bp}$ & $-0.123^{\mathrm{ns}}$ & $-0.708^{\mathrm{ns}}$ & $-0.664^{\mathrm{ns}}$ \\
\hline $\mathrm{IC}_{50} \mathrm{DPPH}$ Pf & $-0.947^{\mathrm{ns}}$ & $-0.998^{*}$ & $-0.979^{\mathrm{ns}}$ \\
\hline $\mathrm{IC}_{50} \mathrm{DPPH} \mathrm{Pp}$ & $-0.313^{\mathrm{ns}}$ & $0.473^{\mathrm{ns}}$ & $0.323^{\text {ns }}$ \\
\hline $\mathrm{IC}_{50}$ ABTS Bf & $-0.962^{\mathrm{ns}}$ & $-0.994^{\mathrm{ns}}$ & $-0.955^{\mathrm{ns}}$ \\
\hline $\mathrm{IC}_{50}$ ABTS Bp & $0.919^{\mathrm{ns}}$ & $0.483^{\text {ns }}$ & $0.534^{\mathrm{ns}}$ \\
\hline $\mathrm{IC}_{50}$ ABTS Pf & $0.840^{\mathrm{ns}}$ & $0.664^{\mathrm{ns}}$ & $0.768^{\text {ns }}$ \\
\hline $\mathrm{IC}_{50}$ ABTS Pp & $0.203^{\text {ns }}$ & $0.850^{\mathrm{ns}}$ & $0.753^{\text {ns }}$ \\
\hline $\mathrm{IC}_{50}$ FRAP Bf & $-0.092^{\mathrm{ns}}$ & $-0.462^{\mathrm{ns}}$ & $-0.067^{\mathrm{ns}}$ \\
\hline $\mathrm{IC}_{50}$ FRAP Bp & $0.799^{\mathrm{ns}}$ & $0.260^{\mathrm{ns}}$ & $0.318^{\mathrm{ns}}$ \\
\hline $\mathrm{IC}_{50}$ FRAP Pf & $0.690^{\mathrm{ns}}$ & $0.471^{\mathrm{ns}}$ & $0.597^{\text {ns }}$ \\
\hline $\mathrm{IC}_{50}$ FRAP Pp & $-0.866^{\mathrm{ns}}$ & $-0.946^{\mathrm{ns}}$ & $-0.986^{\mathrm{ns}}$ \\
\hline
\end{tabular}

ns: nonsignificant; significance $(p<0.05)$. Bf: banana flesh; Bp: banana peel; Pf: plantain flesh; Pp: plantain peel.

Phenolics are secondary metabolites and are broadly dispersed in plant tissues. They are responsible for pigmentation, taste, and flavour in fruits [30]. A large number of phenols such as eugenol are responsible for taste [31]. Phenolic compounds have antioxidant activity which has stimulated nutritional interest [32]. The phenol content was high in all acetone and ethanol extracts of M. sinensis and $M$. paradisiaca which is similar to the phenolic levels detected in a number of medicinal plants such as Terminalia arjuna, $T$. bellerica, T. chebula, and Phyllanthus emblica [33]. Likewise, the observation is in line with the high phenolic content observed in Morus nigra cv. Cherokee, Solanum melongena cv. Blacknite, Vaccinium corymbosum cv. O'Neal, and Capsicum annum as reported by [34] just as [35] also reported similar phenolic content outcomes in the mesocarp and pericarp of Mauritia flexuosa and Theobroma bicolor.

Proanthocyanidins, also termed condensed tannins, are polymers of flavonoid molecules [36] present in fruits and flowers of several plants which function as a defence against biotic and abiotic stress and possess antitumor, antioxidant, and immunostimulatory capacity [37]. Furthermore, proanthocyanidins are hypoglycaemic agents reported to have free radical scavenging capacity [38]. They also have inhibitory activity against cancerous cells in the liver [39] and ovarian section [40]. Proanthocyanidin content is high in the ethanol extracts of $M$. sinensis and $M$. paradisiaca peels and is comparable to that of similar solvent extractants of Brachylaena ilicifolia [41]. In addition, the high proanthocyanidin contents in the acetone extracts of M. sinensis and $M$. paradisiaca fruits are similar to those detected in Cucumis africanus fruit by [42]. However, the low levels in the aqueous extracts are similarly corroborated by qualitative profiles of aqueous extracts of $M$. sapientum and $M$. paradisiaca and ripened Saba banana as well as in bracts of the Karpuravalli, Nendrum, and Poovan cultivars of banana [43-45].

Flavonoids are major secondary metabolites with extensive distribution in plants and pharmacological potentials [46]. They are non-nitrogenous compounds responsible for pigmentation in fruits, leaves, and petals [47], which are majorly sourced from fruits, vegetables, and cereals [48].
Flavonoids, known for their interaction with neurological signalling pathways [49], have therapeutic effects in neurodegenerative disease conditions. Dietary flavonoids have biochemical anticancer mechanisms by making the aryl hydrocarbon receptor (AhR) the target site [50] and similarly in Alzheimer's disease (AD) and atherosclerosis [51, 52] and chemoprevention and disease therapy [53]. They are also key in reducing the risk of chronic conditions and the improvement of blood pressure [54]. Notably, [55] has elucidated the use of dietary flavonoids in alternative medicine in relation to the control and management of epileptic conditions. Flavonoid content was high in the acetone and ethanol extracts of $M$. sinensis and $M$. paradisiaca flesh and peel, including the boiled peel extract in both fruits, but was the highest in the acetone extract of each of the flesh and peel of both fruits, a similar observation in ethyl acetate extracts of the muli cultivar of banana [56]. There was undetected to fairly low flavonoid content in the aqueous extracts of $M$. sinensis and $M$. paradisiaca in this study. However, the flavonoid content in $M$. paradisiaca boiled peel extract in this study is comparable to the observation in the aqueous extract of Rubus niveus fruit [57] and is also comparable to similar pharmacological profiles such as antiproliferative, antioxidant, and enzyme inhibitory activities of Rubus caesius L. [58, 59]. Generally, the higher phytochemical contents detected in the acetone and ethanol extracts over the aqueous extracts of $M$. sinensis and $M$. paradisiaca fruits suggest the superior extractive potency of organic solvents over the somewhat weaker potency in aqueous solvents [60]. This observation, particularly in acetone solvents, is not far-fetched due to the nature of the solvent's polarity, with extensive significance on the components and activity of bioactive compounds [61]. Furthermore, [62] has buttressed the point about organic solvents' high extraction efficiency.

Antioxidants are compounds that neutralise free radicals and can be supplied in diets. Dietary antioxidants have key pharmacologically important roles such as male reproductive health improvement [63], insulin resistance, and lowered risk of type II diabetes [64]. Essentially, antioxidants facilitate regular body functions such as normal cell growth, 
immune support, and prevention of degeneration at molecular levels, including the stemming of premature ageing [65]. Furthermore, research workers have mirrored areas such as the in vitro evaluation of the biological activities of unripe $M$. paradisiaca against the oxidative and cell-damaging phenomenon of lipid peroxidation in the pancreatic organ of rats [66]. Antioxidant potential was evaluated with the DPPH, ABTS, and FRAP assays, in order to account for the variances present in the mode of activity of antioxidants. There was a generally low DPPH activity in the acetone, ethanol, and aqueous extracts of the flesh and peel, as well as the boiled peel extracts in M. sinensis and M. paradisiaca. This could be accounted for due to the reported direct relation between DPPH radical scavenging activity and proanthocyanidin content [67]. Inhibition of $\mathrm{ABTS}^{+}(\%)$ by the extracts was generally higher than in $\mathrm{DPPH}$, alluding to a lower $\mathrm{IC}_{50}$ value than $\mathrm{DPPH}$, which is explainable by the variations in the mechanism in the two radical antioxidant reaction assays. The organic extracts (acetone and ethanol) predominantly had the highest DPPH scavenging activity in the peel, flesh, and boiled peel extract of M. sinensis. This observation can be attributed to the implication of phenolic content in the antioxidative mechanism [68]. The synergistic relationship between phenolic compounds and antioxidant activity in plants has also been elucidated [69-71]. Reference [72] similarly observed good antioxidant scavenging activity in the peel of Solanum tuberosum, Zingiber officinale, Ipomoea batatas, and Raphanus sativus. ABTS inhibition was the highest in aqueous extracts of $M$. sinensis and $M$. paradisiaca peels and was even higher in the boiled peel extracts of $M$. sinensis and $M$. paradisiaca. The high phenolic content can be reflective of the observed antioxidant activity, especially because phenols and especially flavonoids are bioactivity precursors [73-75] and key contributory factors to the antioxidative potential of plants [76, 77].

The FRAP assay is a well-known, reliable approach that measures ferric reducing ability in a redox-linked colorimetric reaction that reduces $\mathrm{Fe}^{3+}$ to $\mathrm{Fe}^{2+}$ [78-81]. The reflectively high FRAP activity on the basis of $\mathrm{IC}_{50}$ valuation in ethanol extracts of $M$. sinensis flesh and peel and $M$. paradisiaca flesh, acetone extracts of $M$. paradisiaca flesh and peel, and aqueous extract of $M$. sinensis peel and M. paradisiaca boiled peel extract can be linked to high flavonoid content such as that seen in the ethanol extracts of $M$. sinensis flesh and peel, acetone extracts of M. paradisiaca flesh and peel, and M. paradisiaca boiled peel extract. This confers the flesh and peel of both fruits as natural antioxidant sources and further connotes the contributory role of secondary metabolites of $M$. sinensis and $M$. paradisiaca in disease prevention [82]. The positive correlation between phenolic content and the ABTS activity in $M$. sinensis peel, $M$. paradisiaca flesh and peel, FRAP activity of $M$. sinensis peel, and $M$. paradisiaca flesh is in conformity with reports of phenolic compounds being related to antioxidant activity [83-85]. However, the general positive and negative correlational patterns indicate an unpredictable correlation between the two pharmacological factors and suggest that none of the polyphenolic constituents contributed exclusively to antioxidant activity, but instead that a combination of the polyphenolic constituents contributed to antioxidant activity $[71,86]$.

\section{Conclusion}

In a bid to further enhance the utility of the phytomedicinal potential of $M$. sinensis and M. paradisiaca fruits, this study has shown their therapeutic potentials on the basis of their polyphenolic constitution and richness, chief of which are flavonoids and phenol in the compartments (flesh and peel) of the fruits. The bioactivity and therapeutic potential of the plant extracts are also largely inclined to the organic-based extraction solvents, with the acetone extracts being dominantly bioactive and thus suggested to be the most pharmacologically preferred extraction solvent. The biological activity reflects the viability of $M$. sinensis and $M$. paradisiaca fruits as useful natural antioxidants, against oxidative stress which improves and buttresses the nutritional acceptability and medicinal capacities, respectively, of the flesh and peel components of these fruits. Furthermore, M. sinensis and $M$. paradisiaca flesh and peel should be incorporated into the human diet due to comparable ferric reducing antioxidant capacity with standard drugs such as rutin. There also portend higher therapeutic benefits upon the combined consumption of the three fruit components.

\section{Data Availability}

The data used to support the findings of this study are available upon request to the authors.

\section{Conflicts of Interest}

The authors declare no conflicts of interest.

\section{References}

[1] R. S. Santhosh and B. Suriyanarayanan, "Plants: a source for new antimycobacterial drugs," Planta Medica, vol. 80, pp. 9-21, 2014.

[2] N. Jain, M. Keating, P. Thompson et al., "Ibrutinib and venetoclax for first-line treatment of CLL," New England Journal of Medicine, vol. 380, no. 22, pp. 2095-2103, 2019.

[3] C. Kanta, I. P. Sharma, and M. A. Shiekh, "Ethnobotanical studies on medicinal plants of Langate area, Kupwara, Jammu and Kashmir, India," Journal of Medicinal Plants Studies, vol. 6, pp. 94-97, 2018.

[4] A. Bhattacharyya, R. Chattopadhyay, S. Mitra, and S. E. Crowe, "Oxidative stress: an essential factor in the pathogenesis of gastrointestinal mucosal diseases," Physiological Reviews, vol. 94, no. 2, pp. 329-354, 2014.

[5] D. Xu, Y. Li, X. Meng et al., "Natural antioxidants in foods and medicinal plants: extraction, assessment and resources," International Journal of Molecular Sciences, vol. 18, p. 96, 2017.

[6] H. Sakakibara, Y. Ichikawa, S. Tajima et al., "Practical application of flavonoid-poor menu meals to the study of the bioavailability of bilberry anthocyanins in human subjects," Bioscience, Biotechnology, and Biochemistry, vol. 78, no. 10, pp. 1748-1752, 2014.

[7] L.-X. Cheng, J.-J. Tang, H. Luo et al., "Antioxidant and antiproliferative activities of hydroxyl-substituted Schiff 
bases," Bioorganic \& Medicinal Chemistry Letters, vol. 20, no. 8, pp. 2417-2420, 2010.

[8] Y. Tang, I. B. Jaganath, and S. D. Sekaran, "Phyllanthus spp induces selective growth inhibition of PC-3 and mewo human cancer cells through modulation of cell cycle and induction of apoptosis," PLoS One, vol. 5, no. 9, Article ID e12644, 2010.

[9] E. Catalano, "Role of phytochemicals in the chemoprevention of tumors," 2016, https://arxiv.org/abs/1605.04519.

[10] R. Kotecha, A. Takami, and J. L. Espinoza, "Dietary phytochemicals and cancer chemoprevention: a review of the clinical evidence," Oncotarget, vol. 7, no. 32, pp. 52517-52529, 2016.

[11] K. W. Lee, A. M. Bode, and Z. Dong, "Molecular targets of phytochemicals for cancer prevention," Nature Reviews Cancer, vol. 11, no. 3, pp. 211-218, 2011.

[12] R. V. Priyadarsini and S. Nagini, "Cancer chemoprevention by dietary phytochemicals: promises and pitfalls," Current Pharmaceutical Biotechnology, vol. 13, pp. 125-136, 2012.

[13] M.-J. R. Howes and M. S. J. Simmonds, "The role of phytochemicals as micronutrients in health and disease," Current Opinion in Clinical Nutrition and Metabolic Care, vol. 17, no. 6, pp. 558-566, 2014.

[14] C. S. Aquino, L. C. C. Salomão, S. M. R. Ribeiro et al., "Carbohydrates, phenolic compounds and antioxidant activity in pulp and peel of 15 banana cultivars," Revista Brasileira de Fruticultura, vol. 38, no. 4, pp. 1-11, 2016.

[15] O. J. Ogbonna, "Phytochemical and proximate analysis, mineral and vitamin compositions of Allium cepa bulb extract," Advances in Biomedicine and Pharmacy, vol. 3, no. 4, pp. 181-186, 2016.

[16] B. O. Oyeyinka and A. J. Afolayan, "Comparative evaluation of the nutritive, mineral and antinutritive composition of Musa sinensis L. (banana) and Musa paradisiaca L. (plantain) fruit compartments," Plants, vol. 8, pp. 1-14, 2019.

[17] M. Z. Imam and S. Akter, "Musa paradisiaca L. and Musa sapientum L., a phytochemical and pharmacological review," Journal of Applied Pharmaceutical Science, vol. 1, pp. 14-20, 2011.

[18] M. Rivera-Cruz, A. Trujillonarcia, G. Cordovaballona, J. Kohler, F. Caravaca, and A. Roldan, "Poultry manure and banana waste are effective biofertilizer carriers for promoting plant growth and soil sustainability in banana crops," Soil Biology and Biochemistry, vol. 40, no. 12, pp. 3092-3095, 2008.

[19] D. Mohapatra, S. Mishra, and N. Sutar, "Banana and its byproduct utilization: an overview," Journal of Scientific and Industrial Research, vol. 269, pp. 323-329, 2010.

[20] P. Goyal, A. Chauhan, and P. Kaushik, "Laboratory evaluation of crude extracts of cinnamomum tamala for potential antibacterial activity," eJBIO, vol. 5, pp. 75-79, 2009.

[21] G. Ehiowemwenguan, A. O. Emoghene, and J. E. Inetianbor, "Antibacterial and phytochemical analysis of Banana fruit peel," IOSR Journal of Pharmacy (IOSRPHR), vol. 4, no. 8, pp. 18-25, 2014.

[22] S. Siddique, S. Nawaz, F. Muhammad, B. Akhtar, and B. Aslam, "Phytochemical screening and in-vitro evaluation of pharmacological activities of peels of Musa sapientum and carica papaya fruit," Natural Product Research, vol. 32, no. 11, pp. 1333-1336, 2018.

[23] G. A. Agbor, J. A. Vinson, J. E. Oben, and J. Y. Ngogang, "Antioxidant effect of herbs and spices on copper mediated oxidation of lower and very low density lipoprotein," Chinese Journal of Natural Medicines, vol. 8, no. 2, pp. 114-120, 2010.

[24] F. U. Ohikhena, O. A. Wintola, and A. J. Afolayan, "Quantitative phytochemical constituents and antioxidant activities of the mistletoe Phragmanthera capitata (sprengel) balle extracted with different solvents," Pharmacognosy Research, vol. 10, pp. 6-23, 2018.

[25] A. Lamien-Meda, M. Nell, U. Lohwasser, A. Börner, C. Franz, and J. Novak, "Investigation of antioxidant and rosmarinic acid variation in the sage collection of the genebank in Gatersleben," Journal of Agricultural and Food Chemistry, vol. 58, no. 6, pp. 3813-3819, 2010.

[26] E. Iqbal, K. A. Salim, and L. B. L. Lim, "Phytochemical screening, total phenolics and antioxidant activities of bark and leaf extracts of Goniothalamus velutinus (airy shaw) from Brunei Darussalam," Journal of King Saud University-Science, vol. 27, no. 3, pp. 224-232, 2015.

[27] R. A. Khan, M. R. Khan, S. Sahreen et al., "Evaluation of phenolic contents and antioxidant activity of various solvent extracts of Sonchus asper (L) hill," Chemistry Central Journal, vol. 6, pp. 1-7, 2012.

[28] P. Jayanthi and P. Lalitha, "Reducing power of the solvent extracts of Eichhornia crassipes (Mart.) solms," International Journal of Pharmacy and Pharmaceutical Sciences, vol. 3, pp. 126-128, 2011.

[29] P. C. Chikezie, C. O. Ibegbulem, and F. N. Mbagwu, "Bioactive principles from medicinal plants," Research Journal of Phytochemistry, vol. 9, no. 3, pp. 88-115, 2015.

[30] B. G. Swanson, "Tannins and polyphenols," in Encyclopedia of Food Sciences and Nutrition, pp. 5729-5733, Academic Press, Cambridge, MA, USA, 2nd edition, 2003.

[31] E. M. Aldred, "Chapter 21- phenols," in Pharmacology: A Handbook for Complementary Healthcare Professionals, pp. 149-166, Elsevier, Amsterdam, Netherlands, 2009.

[32] J. W. Lampe, "Health effects of vegetables and fruit: assessing mechanisms of action in human experimental studies," The American Journal of Clinical Nutrition, vol. 70, no. 3, pp. 475S-490S, 1999.

[33] V. K. Bajpai, S. M. Al-Reza, U. K. Choi, J. H. Lee, and S. C. Kang, "Chemical composition, antibacterial and antioxidant activities of leaf essential oil and extracts of Metasequioa glyptostroboides Miki ex Hu," Food and Chemical Toxicology, vol. 47, no. 8, pp. 1876-1883, 2009.

[34] M. Lutz, J. Hernández, and C. Henríquez, "Phenolic content and antioxidant capacity in fresh and dry fruits and vegetables grown in Chile," CyTA-Journal of Food, vol. 13, pp. 541-547, 2015.

[35] J. Tauchen, L. Bortl, L. Huml et al., "Phenolic composition, antioxidant and anti-proliferative activities of edible and medicinal plants from the Peruvian amazon," Revista Brasileira de Farmacognosia, vol. 26, no. 6, pp. 728-737, 2016.

[36] G. J. Tanner, K. T. Francki, S. Abrahams, J. M. Watson, P. J. Larkin, and A. R. Ashton, "Proanthocyanidin biosynthesis in plants. Purification of legume leucoanthocyanidin reductase and molecular cloning of its cDNA," Journal of Biological Chemistry, vol. 278, no. 34, pp. 31647-31656, 2003.

[37] A. Rauf, M. Imran, T. Abu-Izneid et al., "Proanthocyanidins: a comprehensive review," Biomedicine and Pharmacotherapy, vol. 116, pp. 1-6, 2019.

[38] J. Shi, J. Yu, J. E. Pohorly, and Y. Kakuda, "Polyphenolics in grape seeds-biochemistry and Functionality," Journal of Medicinal Food, vol. 6, no. 4, pp. 291-299, 2003.

[39] Y. Zhang, X. Zhou, W. Tao et al., "Antioxidant and antiproliferative activities of proanthocyanidins from Chinese bayberry (Myrica rubra Sieb. et Zucc.) leaves," Journal of Functional Foods, vol. 27, pp. 645-654, 2016.

[40] Y. Zhang, S. Chen, C. Wei et al., "Dietary compound proanthocyanidins from Chinese bayberry (Myrica rubra 
Sieb. et Zucc.) leaves inhibit angiogenesis and regulate cell cycle of cisplatin-resistant ovarian cancer cells via targeting Akt pathway," Journal of Functional Foods, vol. 40, pp. 573581,2018 .

[41] I. J. Sagbo, A. J. Afolayan, and G. Bradley, "Antioxidant, antibacterial and phytochemical properties of two medicinal plants against the wound infecting bacteria," Asian Pacific Journal of Tropical Biomedicine, vol. 7, no. 9, pp. 817-825, 2017.

[42] T. O. Abifarin, A. J. Afolayan, and G. A. Otunola, "Phytochemical and antioxidant activities of Cucumis africanus L.f.: a wild vegetable of South Africa," Journal of Evidence-Based Integrative Medicine, vol. 24, pp. 1-8, 2019.

[43] O. A. Ogbonna, A. I. Izundu, N. H. Okoye, and A. P. Ikeyi, "Phytochemical compositions of fruits of three Musa species at three stages of development," IOSR Journal of Pharmacy and Biological Sciences, vol. 11, pp. 48-59, 2016.

[44] A. A. Kibria, M. M. Rahman, and A. Kar, "Extraction and evaluation of phytochemicals from banana peels (Musa sapientum) and banana plants (Musa paradisiaca)," Malaysian Journal of Halal Research, vol. 2, no. 1, pp. 22-26, 2019.

[45] X. Laser Mary and V. Judia Harriet Sumathy, "Phytochemical analysis of different varieties of banana bracts and their applications," International Journal of Current Research in Multidisciplinary, vol. 5, pp. 1-12, 2016.

[46] M. Ayaz, A. Sadiq, M. Junaid et al., "Flavonoids as prospective neuroprotectants and their therapeutic propensity in aging associated neurological disorders," Frontiers in Aging Neuroscience, vol. 11, pp. 1-20, 2019.

[47] P. Karak, "Biological activities of flavonoids: an overview," International Journal of Pharmaceutical Sciences and Research, vol. 10, pp. 1567-1574, 2019.

[48] O. D. Adegbaju, G. A. Otunola, and A. J. Afolayan, "Effects of growth stage and seasons on the phytochemical content and antioxidant activities of crude extracts of Celosia argentea L." Heliyon, vol. 6, Article ID e04086, 2020.

[49] J. P. E. Spencer, "Beyond antioxidants: the cellular and molecular interactions of flavonoids and how these underpin their actions on the brain," Proceedings of the Nutrition Society, vol. 69, no. 2, pp. 244-260, 2010.

[50] T. Yang, Y.-L. Feng, L. Chen, N. D. Vaziri, and Y.-Y. Zhao, "Dietary natural flavonoids treating cancer by targeting aryl hydrocarbon receptor," Critical Reviews in Toxicology, vol. 49, no. 5, pp. 445-460, 2019.

[51] M. Burak and Y. Imen, "Flavonoids and their antioxidant properties," Turkiye Klinikleri Journal of Medical Sciences, vol. 19, pp. 296-304, 1999.

[52] A. Castañeda-Ovando, M. d. L. Pacheco-Hernández, M. E. Páez-Hernández, J. A. Rodríguez, and C. A. GalánVidal, "Chemical studies of anthocyanins: a review," Food Chemistry, vol. 113, no. 4, pp. 859-871, 2009.

[53] A. N. Panche, A. D. Diwan, and S. R. Chandra, "Flavonoids: an overview," Journal of Nutritional Science, vol. 5, pp. 1-15, 2016.

[54] K. L. Ivey, A. T. Chan, J. Izard et al., "Role of dietary flavonoid compounds in driving patterns of microbial community assembly," mBio, vol. 10, Article ID e01205, 2019.

[55] J. Y. Kwon, M.-T. Jeon, U. J. Jung, D. W. Kim, G. J. Moon, and S. R. Kim, "Perspective: therapeutic potential of flavonoids as alternative medicines in epilepsy," Advances in Nutrition, vol. 10, no. 5, pp. 778-790, 2019.

[56] I. Fidrianny, R. Kiki Rizki, and M. Insanu, "In vitro antioxidant activities from various extracts of banana peels using ABTS, DPPH assays and correlation with phenolic, flavonoid, carotenoid content," International Journal of Pharmacy and Pharmaceutical Sciences, vol. 6, pp. 299-303, 2014.

[57] K. Muniyandi, E. George, S. Sathyanarayanan et al., "Phenolics, tannins, flavonoids and anthocyanins contents influenced antioxidant and anticancer activities of Rubus fruits from Western Ghats, India," Food Science and Human Wellness, vol. 8, no. 1, pp. 73-81, 2019.

[58] D. M. Grochowski, S. Uysal, G. Zengin, and M. Tomczyk, "In vitro antioxidant and enzyme inhibitory properties of Rubus caesius L," International Journal of Environmental Health Research, vol. 29, no. 3, pp. 237-245, 2019.

[59] G. Zengin, C. Ferrante, I. Senkardes et al., "Multidirectional biological investigation and phytochemical profile of Rubus sanctus and Rubus ibericus," Food and Chemical Toxicology, vol. 127, pp. 237-250, 2019.

[60] C. Sun, Z. Wu, Z. Wang, and H. Zhang, "Effect of ethanol/ water solvents on phenolic profiles and antioxidant properties of Beijing propolis extracts," Evidence-Based Complementary and Alternative Medicine, vol. 2015, Article ID 595393, 9 pages, 2015.

[61] T. V. Ngo, C. J. Scarlett, M. C. Bowyer, P. D. Ngo, and Q. V. Vuong, "Impact of different extraction solvents on bioactive compounds and antioxidant capacity from the root of Salacia chinensis L." Journal of Food Quality, vol. 2017, Article ID 9305047, 8 pages, 2017.

[62] J. O. Unuofin, G. A. Otunola, and A. J. Afolayan, "Polyphenolic content, antioxidant and antimicrobial activities of Vernonia mespilifolia less. used in folk medicine in the Eastern Cape province, South Africa," Journal of EvidenceBased Integrative Medicine, vol. 23, pp. 1-9, 2018.

[63] R. M. Smits, R. Mackenzie-Proctor, A. Yazdani et al., "Antioxidants for male subfertility (review)," Cochrane Database of Systematic Review, vol. 3, pp. 1-235, 2019.

[64] N. Van der Schaft, J. D. Schoufour, J. Nano et al., "Dietary antioxidant capacity and risk of type 2 diabetes mellitus, prediabetes and insulin resistance: the Rotterdam study," European Journal of Epidemiology, vol. 34, no. 9, pp. 853-861, 2019.

[65] K. Kattappagari, C. Ravi Teja, R. Kommalapati, C. Poosarla, S. Gontu, and B. R. Reddy, "Role of antioxidants in facilitating the body functions: a review," Journal of Orofacial Sciences, vol. 7, no. 2, pp. 71-75, 2015.

[66] S. A. Shodehinde and G. Oboh, "Antioxidant properties of aqueous extracts of unripe Musa paradisiaca on sodium nitroprusside induced lipid peroxidation in rat pancreas in vitro," Asian Pacific Journal of Tropical Biomedicine, vol. 3, no. 6, pp. 449-457, 2013.

[67] S. S. Kim, C. G. Hyun, J. Lee et al., "In vitro screening of Jeju medicinal plants for cosmeceutical materials," Journal of Applied Biological Chemistry, vol. 50, pp. 215-220, 2007.

[68] T. O. Elufioye, D. M. Olusola, and A. O. Oyedeji, "Correlation of total phenolic, flavonoid and tannin content of Bryophyllum pinnatum (Lam.) (crassulaceae) extract with the antioxidant and anticholinesterase activities," Pharmacognosy Journal, vol. 11, pp. 1003-1009, 2009.

[69] V. Singh, N. Guizani, M. M. Essa, F. L. Hakkim, and M. S. Rahman, "Comparative analysis of total phenolics, flavonoid content and antioxidant profile of different date varieties (Phoenix dactylifera L.) from sultanate of Oman," International Food Research Journal, vol. 19, pp. 1063-1070, 2012.

[70] M. El Jemli, R. Kamal, I. Marmouzi, A. Zerrouki, Y. Cherrah, and K. Alaoui, "Radical-scavenging activity and ferric reducing ability of Juniperus thurifera (L.), J. oxycedrus (L.), J. 
phoenicea (L.) and Tetraclinis articulata (L.)," Advances in Pharmacological Sciences, vol. 2016, Article ID 6392656, 6 pages, 2016.

[71] I. Fidrianny, H. Suhendy, and M. Insanu, "Correlation of phytochemical content with antioxidant potential of various sweet potato (Ipomoea batatas) in West Java, Indonesia," Asian Pacific Journal of Tropical Biomedicine, vol. 8, no. 1, pp. 25-30, 2018.

[72] K. F. Khattak and T. R. Rahman, "Effect of geographical distributions on the nutrient composition, phytochemical profile and antioxidant activity of Morus nigra," Pakistan Journal of Pharmaceutical Sciences, vol. 28, no. 5, pp. 16711678, 2015.

[73] E. Bendary, R. R. Francis, H. M. G. Ali, M. I. Sarwat, and S. El Hady, "Antioxidant and structure-activity relationships (SARs) of some phenolic and anilines compounds," Annals of Agricultural Sciences, vol. 58, no. 2, pp. 173-181, 2013.

[74] M. Carocho and I. C. F. R. Ferreira, "A review on antioxidants, prooxidants and related controversy: natural and synthetic compounds, screening and analysis methodologies and future perspectives," Food and Chemical Toxicology, vol. 51, pp. 15-25, 2013.

[75] H. Zhao, H. Zhang, and S. Yang, "Phenolic compounds and its antioxidant activities in ethanolic extracts from seven cultivars of Chinese jujube," Food Science and Human Wellness, vol. 3, no. 3-4, pp. 183-190, 2014.

[76] R. C. Kessler, P. Berglund, O. Demler et al., "The epidemiology of major depressive disorder: results from the national comorbidity survey replication (NCS-R)," JAMA, vol. 289, no. 23, pp. 3095-3105, 2003.

[77] J. P. Dzoyem and J. N. Eloff, "Anti-inflammatory, anticholinesterase and antioxidant activity of leaf extracts of twelve plants used traditionally to alleviate pain and inflammation in South Africa," Journal of Ethnopharmacology, vol. 160, pp. 194-201, 2015.

[78] S. Vladimir-Knežević, B. Blažeković, M. B. Štefan et al., "Antioxidant activities and polyphenolic contents of three selected micromeria species from Croatia," Molecules, vol. 16, pp. 1454-1470, 2011.

[79] S. Vladimir-Knežević, B. Blažeković, M. Kindl et al., “Acetylcholinesterase inhibitory, antioxidant and phytochemical properties of selected medicinal plants of the lamiaceae family," Molecules, vol. 19, pp. 767-782, 2014.

[80] M. F. Mahomoodally, K. Sinan, K. Bene et al., "Bridelia speciosa Müll.Arg. stem bark extracts as a potential biomedicine: from tropical western Africa to the pharmacy shelf," Antioxidants, vol. 9, pp. 1-28, 2020.

[81] K. I. Sinan, A. Chiavaroli, G. Orlando et al., "Biopotential of bersama abyssinica fresen stem bark extracts: UHPLC profiles, antioxidant, enzyme inhibitory and anti-proliferative propensities," Antioxidants, vol. 9, pp. 1-18, 2020.

[82] S. Shan, X. Huang, M. H. Shah, and A. M. Abbasi, "Evaluation of polyphenolics content and antioxidant activity in edible wild fruits," BioMed Research International, vol. 2019, Article ID 1381989, 11 pages, 2019.

[83] F. L. Song, R. Y. Gan, Y. Zhang, Q. Xiao, L. Kuang, and H. B. Li, "Total phenolic contents and antioxidant capacities of selected Chinese medicinal plants," International Journal of Molecular Sciences, vol. 11, no. 6, pp. 2362-2372, 2010.

[84] T. T. Chai and F. C. Wong, "Whole-plant profiling of total phenolic and flavonoid contents, antioxidant capacity and nitric oxide scavenging capacity of Turnera subulata," Journal of Medicinal Plants Research, vol. 6, pp. 1730-1735, 2012.
[85] T. M. Chaouche, F. Haddouchi, R. Ksouri, and F. AtikBekkara, "Evaluation of antioxidant activity of hydromethanolic extracts of some medicinal species from south Algeria," Journal of the Chinese Medical Association, vol. 77, no. 6, pp. 302-307, 2014.

[86] P. Ngamdee, U. Wichai, and S. Jiamyangyuen, "Correlation between phytochemical and mineral contents and antioxidant activity of black glutinous rice bran and its potential chemopreventive property," Food Technology and Biotechnology, vol. 54, pp. 282-289, 2016. 